\title{
The role of non-wood forest products in poverty alleviation and food security in Urban Ghana
}

\author{
Mawutor K. Glover ${ }^{1}$, Edinam K. Glover ${ }^{2}$, * \\ ${ }^{1}$ Department of Agro Enterprise, Faculty of Applied Sciences, Ho Polytechnic, P. O. Box 217, Ho, Ghana \\ ${ }^{2}$ Faculty of Law, P. O. Box 4, FI-00014 University of Helsinki, Helsinki, Finland \\ Email address: \\ mgloverk@yahoo.com (M. K. Glover), eddie.glover@helsinki.fi (E. K. Glover)
}

\section{To cite this article:}

Mawutor K. Glover, Edinam K. Glover. The Role of Non-Wood Forest Products in Poverty Alleviation and Food Security in Urban Ghana. Agriculture, Forestry and Fisheries. Vol. 3, No. 4, 2014, pp. 307-312. doi: 10.11648/j.aff.20140304.23

\begin{abstract}
Non Wood Forest Product (NWFP) is as old as the existence of humans and has gained increasing importance. The study focused on processing NWFPs in urban Ghana with special reference to the bushmeat commodity chain that supplies the urban areas. It described the existing forms of bushmeat processing requirements and constraints. It also examined the contribution of bushmeat to poverty alleviation and food security through its use, processing and trade as a NWFP. Methods for data collection involved the use of qualitative research approach in form of selective case study approach. In line with this approach, the study used both participant observation combined with focus group discussion to collect information from a cross section of primary actors in the bushmeat trade. Results showed that processing bushmeat for sale vary from place to place. It is conveyed to the major markets either smoked or fresh. Those using bushmeat for medicinal purposes cut the meat into various parts and dry them for their clientele. Results also showed that bushmeat trading activities involve a chain of actors composed of hunters, wholesalers and chop bar owners/retailers. This livelihood activity contributes highly to food security and household incomes of actors of the trade.
\end{abstract}

Keywords: Bushmeat, Food Security, Ghana, Non Wood Forest Products, Poverty Alleviation, Processing

\section{Introduction}

\subsection{Non Wood Forest Products: An Overview}

Non wood forest products (NWFPs) appear to have drawn particular attention in international development programmes, especially during the last decade. Because of their relatively low economic contribution, NWFPs have also been called: minor forest products, other forest products, other economic products, or non-timber forest products. It should be pointed out that there is a considerable difference between "non-wood" forest products and "non-timber" forest products. The latter term refers to products that are tree-derived but do not necessitate felling trees [1]. Non-wood forest products have been defined as "all goods of biological origin other than wood in all its forms, as well as services derived from forest or any land under similar use" (Ibid.). NWFPs are an important part of the economies of many countries, and also serve as an effective tool in the conservation of forests and other ecosystems. Rural households, especially those living on forest fringes across the world, are extractors of these resources and it contributes to their food, energy and other aspects of their welfare [2, 3].

Throughout Ghana forests form an integral part of the rural economy, providing subsistence goods and services as well as items of trade. NWFPs have served as a source of food and nutrition, medicine, ornaments, fiber materials for construction, utensils, clothing, packing, and more recently as raw materials for further processing at artisan and industrial levels [4, 5]. Examples of NWFPs of vegetal origin include a wide range of products such as rattan, resins, essential oils, latex, ornamental plants, nuts, species of fruits and seeds [6]. Animal products include game, fish, birds, eggs, honey and silk (Ibid.). Bushmeat, nuts (such as cola and sheabutter), canes, medicinal plants and building materials (e.g. roof material obtained from Dalbergia sissoo) are the most important NWFPs of Ghana [2, 3]. It is known that appropriate management and sustainable harvesting of such resources have a major role to play in our food security. Recent developments in the livestock industry show the complimentary effect of wildlife to food security in the country. It is also known that bushmeat has over the years contributed significantly to the total animal protein intake of 
Ghanaians and in particular, those in the rural areas $[4,5]$. Several statistical analyses and studies (see [6-9]) have confirmed the role of bushmeat households living in extreme poverty (daily per capita income less than US \$1), especially as a source of cash income but also as a key food during the lean agricultural season. NWFPs are an important part of the economies of many countries, and also serve as an effective tool in the conservation of forests and other ecosystems. Davies [10] noted that national estimates of the value of the domestic trade in bushmeat range from US \$ 42 to US \$ 205 million across countries in West and Central Africa. This being the case, the existing information about the status of the resource base, the probable impact of hunting and processing practices, etc. is lacking [3-4]. One of the important challenges facing Ghana today is how to feed the population and alleviate rural poverty. In countries like Ghana where other forms of meat are not readily available to the people, bushmeat may be the only animal protein source that is handy and affordable. This being the case, proper development of the bushmeat sector is constraint by lack of reliable information and data on which to make informed decisions and formulation of appropriate policies to support the industry. Bushmeat hunting and processing methods are still largely traditional in both techniques and tools used. It is within this context that this study is of much important as it addresses itself to assessing the extent to which the processing of bushmeat, a non wood forest product, contributes to the nation's food security and human welfare. The promotion of natural woodlands can and should complement the objectives of rural development, and appropriate forest management. Addressing food security problems are crucial for the future development of Ghana.

Against this backdrop, the present study was undertaken generally for the purpose of providing a scientific analysis of bushmeat processing to ensure subsistence needs of urban and rural dwellers while developing and conserving the forests. More specifically, the aims of the study were to describe existing forms of bushmeat processing requirements and constraints and to assess the contribution of bushmeat to poverty alleviation and food security through use, processing and trade of bushmeat as a non-wood forest product.

\subsection{Bushmeat as Valuable Non Wood Forest Product (NWFP)}

This section focuses on one important Non Wood Forest Product (NWFP) whose extraction has moved from traditional subsistence to commercial trade and has become a livelihood support for both urban and rural dwellers. This NWFP is bushmeat, also referred to as game or wild meat. Bushmeat is an umbrella term for all wild-caught mammal meat and it can range from cane rats to gorillas [10]. In simple terms they could be said to be meat of animals living in the wild. Bushmeat, the meat of wild animals is a NWFP with important livelihoods dimensions, namely animals hunted for consumptive use linked to local livelihoods. There is a general consensus that bushmeat is widely consumed in both rural and urban areas and it is an important source of protein [11]. As noted earlier, bushmeat (the meat of wild animals) has traditionally been a natural protein source for people in West and Central Africa [12] In a study, Bowen-Jones et al. [13] and Milner-Gulland et al. [14] realized that during the past decades, bushmeat hunting and trade has become a widespread commercial, with severe negative consequences on wild animal populations. They added that as human populations continue to grow and poverty increases, increasing numbers of people are becoming dependent on bushmeat and on the income opportunities from the trade. A study carried by Bowen-Jones et al. [13] found that bushmeat is transported from forests (where the hunting mainly takes place to markets within local communities or to larger markets in urban centres, where it is then sold or traded.

A great number of animal species can be found in these markets, ranging from birds, reptiles, bats, rodents and antelopes to larger mammals such as elephants, buffalos, leopards and primates. They added that the current rate of exploitation is not only unsustainable but also indiscriminate, i.e. all animals are taken whether they are common or endangered. Similar survey of bushmeat markets across West Africa conducted by Cowlishaw et al. [15] and Ntiamoa-Baidu [16] found that the current trade is dominated by smaller mammals, with rodents such as the grasscutter/cane rat (Thryonomys swinderianus) being the most frequently traded and consumed bushmeat species (It has been suggested that this is the result of an extinction filter: vulnerable taxa (slow reproducers) such as primates and other large mammals have been historically depleted, so that mainly species with fast reproduction such as rodents and small antelopes are now hunted [15]. As a matter of fact, Stephenson [17] reported that the ratio of rodents to other taxa for sale in the local bushmeat markets can thus be a rough estimate of the impact hunting has had on local wild animal populations, indicating a depletion of large bodied species. As stated by Bowen-Jones et al. [13] and Milner-Gulland et al. [14], the hunting for wildlife in the humid tropics, particularly in West and Central Africa, poses a serious threat not only to the biological diversity and to the ecological processes, but also to future generations who are highly dependent on bushmeat as a source of protein and income.

\subsection{Bushmeat Trade in Ghana}

In the areas near urban centres of Ghana, little or no NWFP exploitatation occurs, but there are NWFP related activities like handicrafts and bushmeat processing enterprises [18]. Various species of fauna and flora abound in Ghana especially the southern sector due to suitable environmental conditions. In his survey of the country, Thompson found out that the forest and savannah regions are teemed with game. Asibey (cited in [16]) noted that most large cocoa farms in the Brong-Ahafo region, which support the county's economy today, would not have been were it not have been bushmeat which provided protein for the 
farmer and his family.

In the past, bushmeat was one of the important sources of animal protein for people living in the hinterland where fish supplies were limited. Communities living on forest fringes and grasslands were the major consumers of bushmeat but in recent times, due to improvement in transportation network and higher premiums paid for it in most towns and cities, bushmeat is readily available in markets in most towns and cities in the country such as Techiman, Kumasi, Accra, Secondi-Takoradi, Abetifi and many others (where studies have been carried out). Not only is bushmeat an important dietary item, it is also an important trade commodity and the source of livelihood for many people. The trade has created jobs and revenue for people involved in its transaction.

\section{Material and Methods}

\subsection{The Study Area}

Ghana lies on the Gulf of Guinea. It is a moderately sized but densely populated country in West Africa (238,540 square kilometres; 25 million people), that encompasses humid tropical forests in the south and arid savannas in the north. Nevertheless, Ghana remains rich in resources and retains a great deal of economic potential. Agriculture forms the basis of the economy, accounting for 40 per cent of GDP and employing 60 per cent of the workforce, primarily as smallholders. Of all agricultural produce, cocoa is the most important crop, comprising one of Ghana's principal export commodities (second only to gold and surpassing timber).

\subsection{Methodology}

\subsubsection{Selective Case Study Approach}

Methods for data collection involved the use of qualitative research approach in form of selective case study approach [19] to explore the existing forms of bushmeat processing requirements and constraints in Takoradi, Techiman and Makessim in Ghana. As mentioned earlier, the study also analysed the contribution of bushmeat to food security and income generation through its use, processing and trade as a non-wood forest product. The case study approach has been employed because of its relevance in the field of agriculture and forestry research. As stated by Robson [20] case study is the development of detailed intensive knowledge about a single case or a small number of cases. With reference to the work of Casley and Lury [21] this involves a detailed examination of relatively few persons or items and helps to conduct an in-depth analysis of a particular phenomenon. Robson [20] points out that using this approach; information is usually collected through a range of techniques such as observation, interviewing and documentary analysis. He added that this approach does not only help in explaining and describing phenomenon by studying few cases but also, provides systematic way of looking at events collecting data, analyzing and reporting results [Ibid., 22]. Thus oral accounts produced through the interactions and conversations with informants formed the basis on this report.

In line with the selective case study approach, this study used both participant observation combined with focus group discussion for collecting basic information from study area residents. These various techniques of the research approach are further elaborated in the following sections:

\subsubsection{Participant Observation}

The research approach also included the use of participant observation as a complementary approach in collecting data. Participant observation is seen as a means of selecting and recording of behaviours of people in their environment [23]. Participant observation is useful for generating in-depth descriptions of organization or events, for obtaining information that is otherwise inaccessible, and for conducting research when others methods are inadequate. In this study therefore, apart from the conversational approach with informants, in assessing the practices of the selected traders, participant observation was a very important tool also for this study [22, 24].

A number of bushmeat traders were followed to their market stalls where opportunities were also taken to have informal discussions with them. As stated by DeWalt et al. [25], observable details and more hidden details (like taboo behaviour) are more easily observed and understandable over a period of time in order to discover discrepancies between what participants say - and often believe - should happen (the formal system) and what actually does happen, or between different aspects of the formal system; in contrast, a one-time survey of people's answers to a set of questions might be quite consistent, but is less likely to show conflicts between different aspects of the social system or between conscious representations and behavior tool [Ibid.].

\subsubsection{Focus Group Discussions}

Apart from participant observation, focus group discussions (FGD) [26, 27] were held for a cross section of the five primary actors in the bushmeat trade. The five primary actors in the bushmeat trade are namely commercial hunters and farmer hunters, all of whom are men based in local rural areas; and wholesalers, market traders and chop bar owners, all of whom are women based in the city. Bushmeat is freely traded between all actors and actor groups, but the main trade route is from commercial hunters to wholesalers to chop bars.

Focus group discussions were also held with a male group as well as a group of female participants respectively to get more insight on their general impressions about bushmeat. FGD is important for filling in the meanings and feelings behind some of the statistics presented [28, 29]. Focused discussion group enabled detailed discussion of certain topics among small group of people fully aware of or concerned with the subject matter. The aim was to initiate the social participation, to probe for in-depth details, validate, determine further actions, make decisions, and focus ideas on aggregate data at the community level for the study area. As stated by Messerschmidt [30], people tend to 
feel more comfortable expressing their views on a topic of mutual interest within a focus group than they are confronted alone by a researcher whom they may think has power or authority over them or who may have divergent views or interests or some prior assumptions with which they do not fully agree. The use of FGD in combination with participant observation and interviews helped to further clarify important issues that could not have been clarified using only one research technique.

\subsubsection{Secondary Data Collection}

Taking into account the secondary data available, various themes were identified under which data was assessed with special focus on the processing of bushmeat as an example of NWFP.

Data were drawn from books journals, conference proceedings, and progress reports, articles on related studies, the internet and other publication that has background information relevant to the study. Information was also obtained through the analysis of grey literature and peer-reviewed academic documents [22].

\section{Result and Discussions}

\subsection{The Processing of Bushmeat in Ghana}

\subsubsection{Methods of Processing}

Bushmeat is the meat of wild animals, usually from forests. It is an important food source in both rural and urban areas. Processing bushmeat for sale vary from place to place. It is conveyed to the major markets either smoked or fresh. In this context, smoking is the process of preserving, cooking, or flavouring food by exposing it to the smoke from burning or smouldering plant materials, most often wood.Various preserved foods Food preservation is the process of treating and handling food in such a way as to stop or greatly slow down spoilage to prevent foodborne illness while maintaining nutritional value, texture and flavor. Fresh meat, which is the most common form for immediate consumption, is sold in local markets.

Results indicate that the methods of processing bushmeat for preservation vary according to locality and resources. Different kinds of traditional methods are employed to process and preserve bushmeat for consumption and storage. These methods include smoking, drying, salting, frying and fermenting and various combinations of these. The study also shows that smoking is the most widely practised method in Ghana. Results for the current study are in consistent with the findings of Mendelson et al. [31] and Opare-Ankrah [32]. The study revealed that practically all species of bushmeat available in the country can be smoked and traditional method of smoking is widespread in use, suitability and acceptability, despite its limitations.

Facts distilled from the literature analysis undertaken revealed that because smoking is the only means of preservation, hunters operating at distances of more than 15 $\mathrm{km}$ from their base smoke the meat on site in the bush. The study also revealed that smoking also facilitates transportation and reduces the weight. Smoking, especially of big animal, takes at least two days. Many consumers prefer smoked meat [cf. 32, 33].

It was observed that those using bushmeat for medicinal purposes cut the meat into various parts (bones, skull, skin, hair, tails jaws, intestines, and limbs) and dry them for their clientele. Results also indicate that salting is restricted by the availability of salt. Biltong (i.e. meat that is salted and cut into strips and dried in the sun) can be prepared where a combination of salt and sunshine is available [34]. More systematic work in this area is necessary to cover the wide range of wild animals eaten, as well as the nutritional impact of prevailing methods of preparation and preservation.

\subsubsection{Various Ways of Smoking}

The study revealed that though the end product after smoking might be the same, the process of doing this is in two forms: One of the ways is to dip the carcass in boiling water for the hair on its body to be soft enough to be scraped with a knife. A second process is exposing the carcass to flames to burn off the hairs after which they are open up and smoked. It was observed that meat hygiene and health status of the people processing the meat is not a priority in the country. Compared to inspection of domestic meat processors, health inspectors do not visit these people periodically. Meat hygiene and health status of personnel processing meat must be the concern of the government. The promotion of better meat hygiene and health status should include (a) processing of carcasses takes place in dust and fly-free conditions, (b) personnel working with skinned carcasses should be required to be bathed, dressed in clean clothing, and to be free of disease or unhealed sores and (c) facilities for tool sterilization and hand washing for carcass processors must be made continuously available.

\subsubsection{Standards for Bushmeat Processing and Marketing}

The results show that the standards for bushmeat processing and marketing vary from one area to the other. Results indicate the absence of rules or standards for the bushmeat trade in Ghana. The study also shows that the quality of bushmeat offered for sale on the markets, varies widely. Results for the current study are consistent with the findings of Mandelson et al. [31] and Opare-Ankrah [32]. The study revealed that whilst there may be standards set to ensure domestic meat hygiene, these do not either seem to apply to bushmeat or are totally ignored when it comes to bushmeat marketing and processing. Similar study carried by Ntiamoa-Baidu [34] found that this is not a case peculiar to traders in Ghana but to the whole of the West Africa sub region. He added that, there are practically no rules and standards regarding bushmeat processing and marketing. Opare-Ankrah [32] has also argued that animals could be in traps for a day or two and even more before taken to the village and then transported to the market. Most often these are near decomposition and are immediately smoked to put them in good "shape". In a similar study with male traders in Ghana, she found that these traders find it cheaper to by from the hunters and they (traders) gain more after "treating" and 
selling them. Furthermore, it was evident that carcass parts, especially those of the larger mammals, often contain maggots Opare-Ankrah [Ibid.]. These observations provide a plausible practical explanation that they are larger and in order to have the smoked flavour, they are put on low heat which cannot penetrate deep into the meat. The study also shows that the longer the delay in selling meat, the higher the chances of decomposition. Also, the manner in which the carcass is prepared for smoking counts very much. The carcass preparation often takes the form of opening up, spreading and pinning on filthy stands to allow a wider surface for the heat to take effect. In the absence of paved floors the chances of meat contamination are always high. Similarly, since the workers lack safety standards, consumers find it difficult to differentiate between carcasses killed from poisoning and those from approve methods.

\subsubsection{Marketing Channels for Bushmeat Trade in Ghana}

This state of commercialised meat can be an indicator of the abundance of fauna in the producing areas. The results show that there are various ways and conditions through which the bushmeat reaches the consumer. Sometimes it reaches the consumer hidden in sacs, baskets, buckets, cartons and other containers. The product could also be carried on the head, on two wheelers or in a vehicle. Various middlemen come between the hunter and the consumer.

The results of the current study indicate that the actual production of bushmeat for the urban consumer has four primary steps: extraction (from farmbush-matrix habitats), transport (to the city), processing (dressing and smoking) and retail (sales to the public). It was observed that the roles of the different actors are reasonably well defined with respect to bushmeat extraction (hunters only) and retail (market traders and chop bars). Results also show that transportation and processing, however, are less specialized: most actor groups use transport to some extent (with the exception of chop bars) and all actor groups dress and smoke fresh carcasses. Nevertheless, transportation requirements do vary substantially between the different actors. The sale of bushmeat also provides valuable income for rural households living in extreme poverty. However, over-exploitation can lead to the local extinction of threatened species. If too many species become threatened or extinct, bushmeat is unable to provide a sustainable source of income and food security for rural households. The results for the current study are consistent with the findings of Ntiamoa-Baidu [16]: The study revealed that estimates of bushmeat traded in Ghana annually shows that, a significant number of animals are traded in both rural $(2,321,876)$ and urban areas $(6,145,379)$ in the country. Based on a nation-wide average market price of $\$ 2000.00$ per $\mathrm{kg}$, the value of bushmeat marketed annually estimated to be $\notin 183,462,000,000$, equivalent to US $\$ 83,391,740$ (it points to the fact that the trade is the livelihood for many people in the country) [Ibid].

A household and marketing study on NWFP was conducted by Falconer [5] in southern Ghana. The study describes among others the utilization and significance of forest foods, medicines, construction materials and household goods for the rural population. In addition, it presents the processing of, and trade in Marantacea leaves, medicinal plants, canes and bushmeat. This study confirmed that many forest products and services are important to the livelihood of the rural poor. According to Ntiamoa-Baidu [16], there is a high demand for bushmeat because it continues to form a significant source of animal protein and over $80 \%$ of Ghanaians both rural and urban would consume it if available. A considerable number of studies have been conducted on the bushmeat trade in Ghana [5-9, 13, 16, 18, 32, 33]. This study seeks to establish the underlying causes which motivate young people to get involved in the processing and also how people depend on the harvesting and sale of bushmeat as their livelihood strategy. These are important to the study because hunting was done traditionally by older men and money was not their main motivation. Presently, hunting and the sale of animals has become a full time and part time job for many young men and women whose primary livelihood depends on it.

\section{Conclusion}

It has been established that bushmeat is widely consumed in both rural and urban areas in Ghana. According to this study, processing of bushmeat, a non wood forest product ensures food availability at household level; contribute to income generation and nutritional status within households. Hunters make significant profits, indicating that the bushmeat trade has the potential to contribute to the nation's food security and human welfare. It also has the potential to make a substantial economic contribution to rural households.

Comparison with the existing literature suggests that the structure and operation of the bushmeat trade in Ghana is typical of the trade in many other parts of West Africa. There are five main types of actors who participate in the bushmeat commodity chain, namely, commercial hunters, farmer hunters, wholesalers, market traders and chop bar owners. Findings indicate the absence of rules or standards for the bushmeat trade in Ghana. The study also shows that the quality of bushmeat offered for sale on the markets, varies widely. Promotion of better meat hygiene and health status should include: processing of carcasses in dust and fly-free conditions; personnel working with skinned carcasses should be required to be bathed, dressed in clean clothing, and to be free of disease or unhealed sores, and facilities for tool sterilization and hand washing for carcass processors must be made continuously available.

\section{References}

[1] Simmons, A. J. 1996. ICRAF's strategy for domestication of non-wood tree products. Non-wood forest products 9. FAO, Rome, Italy. pp. 8-22. 
[2] Falconer J. \& Arnold J.E.M. 1989. Household food security and forestry: an analysis of socioeconomic issues. Community Forestry Note 1. FAO, Rome.

[3] Ros-Tonen, M. A. F. \& Wiersum, K. F. 2003. The importance of non-timber forest products for forest-based rural livelihoods: An evolving research agenda. Paper presented at the International Conference on Rural Livelihoods, Forests and Biodiversity. May 19-23, 3003. Bonn, Germany.

[4] FAO, 1995. Report of the International Expert Consultation on Non-Wood Forest Products. Yogyakarta, 17-27 January 1995, FAO: Food and Nutrition Division, Rome.

[5] Falconer, J. 1993. Non-timber forest products in Southern Ghana: Main report. Overseas Development Administration (ODA).

[6] Dei, G.J. S. 1989. Hunting and Gathering in a Ghanaian Rain Forest Community. Ecology of Food and Nutrition, 2:225-243.

[7] Dei, G.J. S. 1991. The Deitary Habits of a Ghanaian Farming Community. Ecology of Food and Nutrition, 2: 225-243.

[8] Dei, G.J. S. 1991. A Ghanaian Town Revisited: Changes and Continuties in Local Adaptive Strategies, African Affairs, 91(362): 95-120.

[9] de Merode, E.K. H. and Cowlishaw, G. 2004. The value of Bushmeat and Other Wild Foods to Rural Households Living in Extreme Poverty in the Eastern Democratic Republic of Congo. Biological Conservation. 118: 573-581.

[10] Davies, G. 2002. Bushmeat and international development. Conservation Biology 16: 587-589.

[11] Adams, W.M. 2004. Against Extinction: The story of conservation, Earthscan, UK.

[12] Wilkie, D. S. \& Carpenter, J. F. 1999. Bushmeat hunting in the Congo Basin: an assessment of impacts and options for mitigation, Biodiversity and Conservation, 8, 927-955.

[13] Bowen-Jones, E., Brown, D. \& Robinson, E. J. 2002. Assessment of the solution orientated research needed to promote a more sustainable bushmeat trade in Central and West Africa. Report to the Wildlife and Countryside Directorate, DEFRA.

[14] Milner-Gulland, E.J., Bennett, E.L. \& The Society for Conservation Biology 2002 Annual Conference Wild Meat Group (2003) Wild meat - the bigger picture. Trends in Ecology and Evolution 18: 351-357.

[15] Cowlishaw, G., Mendelson, S. \& RowcliVe, J. M., 2005. Structure and operation of a bushmeat commodity chain in southwestern Ghana. Conservation Biology 19, 139-149.

[16] Ntiamoa-Baidu, Y. 1998. Wildlife Development Plan 1998-2003. Volume 6. Sustainable Use of Bushmeat. Rupublic of Ghana. Wildlife Department, Ministry of Lands and Forestry, Accra.

[17] Stephenson. P. J. 2003. The future directions of WWF'S bushmeat work in Africa. WWF.
[18] Byron N. \& Arnold M. 1999. What futures for the people in tropical forest. World Development 27(5): 789-805.

[19] Hakim, C. 1987. Research Design: Strategies and Choices in the Design of Social Research, London, Unwin Hyman, pages $61-75$.

[20] Robson, C. 2002. Real World Research, Second Edition, Blackwell Publishing, U K.

[21] Casley, D.J. \& Lury, D.A. 1987. Data Collection on Developing Countries, Second Edition, Oxford University Press,U.K.

[22] Bryman, A. 2004. Social research methods. Second Edition. 592p.

[23] Brookes, D. 2007. Understanding qualitative research and its value in healthcare. Nursing Times.Net, 103:32-33. Available at: www.nursingtimes.net [Accessed 05/02/2014].

[24] Flick, U. 2002. An introduction to qualitative research. Second edition, Sage, London. $310 \mathrm{p}$.

[25] DeWalt, K. M., DeWalt, B. R., \& Wayland, C. B. 1998. Participant observation. In: H. R. Bernard (Ed.), Handbook of methods in cultural anthropology. Walnut Creek, CA: AltaMira Press. pp. 259-299.

[26] Denzin, N. K. \& Lincoln, Y.S. (eds.) 2000. Handbook of qualitative research, Second edition. Thousan Oaks, California: Sage.

[27] Curasi, C.F. 2001. A critical exploration of Face-to-Face interviewing vs. Computer-mediated interviewing. International Journal of Market Research, 43: 361-75.

[28] May, T. 1997. Social research: Issues, methods and processes. Buckinggham London. Open University Press.

[29] Silverman, D. 2001. Interpreting qualitative data. Methods for analyzing talk text and interaction. Second edition. Sage Publications, London. 325 p.

[30] Messerschmidt, D. A. 1995. Rapid appraisal for community forestry: RA Process and Rapid Diagnostic Tools, IIED, London. $136 \mathrm{p}$.

[31] Mendelson, Samantha, Cowlishaw, Guy \& Rowcliffe, J. Marcus 2003. Anatomy of a Bushmeat Commodity Chain in Takoradi, Ghana. The Journal of Peasant Studies, 31(1): 73 -100 .

[32] Opare-Ankrah, Y. 2007. The bushmeat trade, livelihood securities and alternative wildlife resources. A Case Study of Mankessim and its environs in the Mfantseman District (Ghana). MPhil. Thesis in Development Studies, Norwegian University of science and Technology, Trondheim. $126 \mathrm{p}$.

[33] Swensson, J. 2005. Bushmeat Trade in Techiman, Ghana, West Africa. Department of Animal Ecology, Committee of Tropical Ecology, Uppsala University, Uppsala, Sweden.

[34] Ntiamoa- Baidu, Y. 1992. Local Perceptions and Values of Wildlife Reserves to Communities in the vicinity of Forest National Parks in Western Ghana in a report on protected area development in south-western Ghana, Oxford Environment and Development Group, U.K. 